\title{
Supraglottic Cancer pT3 TNM Finding v8
}

National Cancer Institute

\section{Source}

National Cancer Institute. Supraglottic Cancer pT3 TNM Finding v8. NCI Thesaurus. Code C133104.

Suprag lottic cancer with tumor limited to larynx with vocal cord fixation and/or invading any of the following: postcricoid area, preepiglottic space, paraglottic space, and/or inner cortex of thyroid cartilage. (from AJCC 8th Ed.) 